\title{
Revisions of Redemption: Rabelais's Medlar, Braguette and Pantagruelion Myths
}

\author{
CAMILLA J. NILLES
}

T he Renaissance recreated human nature in a new image, seeing in each individual a harmonious union of body and soul that reflected the harmony of the universe, restoring humankind to a position of dignity and worth within divine creation. The same design of recreation and redemption informs Rabelais's work and has been the topic of a number of recent studies, including Dennis Costa's, Edwin Duval's and David Quint's. ${ }^{1}$ All three studies have directly related the theme of redemption to Christian doctrine, establishing a parallel that links the giants' growth and evolution to the unfolding of salvation history and places human activity in the context of transcendent reality. Humankind is ennobled by its contact with the divine, human endeavour is sanctioned and condoned by its participants in God's master plan. Reading Rabelais in the light of Biblical subtexts is clearly useful and rewarding. It helps define his conception of the relationship between the human and the divine and of humankind's role in the realization of divine will. Yet it excludes a relationship of equal importance in Rabelais's work, the relationship of hummans to Nature, just as it neglects the way the individual's status as a natural creature affects his or her material and spiritual development.

The present study explores three redemption myths in Rabelais: the story of the medlars in the opening chapters of Pantagruel, the history of the braguette related by Panurge in Chapter Eight of the Tiers Livre, and the praise of Pantagruelion, which concludes the Tiers Livre. It focuses on a subtext that played a role in Rabelais's thought as determinant as his Evangelism - the subtext provided by Rabelais's own medical knowledge of the human body and of the plants he used to strengthen and cure it. While the end of human progress may ultimately be total reconciliation 
with the divine, the source of that ascending trajectory is firmly located in material reality--in natural phenomena and biological impulses.

Shortly after Cain slew Abel, medlars ("mesles") sprang from the earth soaked by the victim's blood. When eaten, the first chapter of Pantagruel tells us, they caused swelling in various parts of the human anatomy. Those who developed swelling all over their bodies became the first giants, whose progeny, according to Edwin Duval, would redeem Cain's offense against humankind (165). David Quint assigns an even more important role to the medlars, seeing in them the very agent of redemption, a "eucharistic" fruit which delivers humankind from the evil effects of Eden's forbidden apples (179). Given the critical attention the medlar myth has recently generated, ${ }^{2}$ it is surprising that no one has asked why Rabelais should choose to distinguish the humble medlar and elevate it to such prominence. The fruit's significance derives from its medicinal powers, with which Rabelais was no doubt well acquainted: used to stanch blood, in particular menstrual flow and hemorrhoidal bleeding, the medlar alone would absorb the mark left by the fratricide. The medlar's specific virtues, along with its hollow, rounded shape, stimulated interesting associations in the popular imagination. Nicknamed "open-arse" (an English translation provided by Cotgrave $^{3}$ ), the medlar was identified with both the buttocks and with female genitalia. ${ }^{4}$ Shakespeare draws on popular traditions when he uses the medlar as a metaphor for female sexuality in Mercutio's taunting remarks to the love-sick Romeo:

Now will he sit under a medlar tree, And wish his mistress were that kind of fruit As maids call medlars, when they laugh alone. Oh, Romeo, that she were, Oh, 'that she were, An open et cetera [-arse], thou a poperin pear.

The medlar myth actually reverses the Biblical account on which it is modelled. As David Quint points out, the sprouting of medlars and the growth they occasion directly contradicts the Bible's assertion that the land on which Abel was murdered remained sterile (179). Now we see that, in an even more dramatic reversal, the Messiah is displaced by a fruit serving as a metaphor of the reproductive organs, the spiritual gives way to the material, ${ }^{5}$ recovered unity to images of generation and proliferation. 
The same pattern of displacement is repeated in the second redemption myth, the story of the braguette's origins, which Panurge relates to justify his eccentric new costume. At the beginning of the Golden Age, Panurge tells us, Nature created plants and furnished them with a variety of devices to protect their seed. Man was given dominion over all forms of vegetation, but he alone was not provided with a natural means of protecting the source of procreation. With the advent of the Iron Age, animals and vegetables grew restless and rebelled against man's authority, forcing him to arm himself in order to reassert his power and reestablish Nature's divine scheme. He began by safeguarding the member that assured the continuity of his race and, modelling his invention on Nature's own protective devices, he covered his nakedness with fig leaves, "les quelles sont naïfves, et du tout commodes en dureté, incisure, frizure, polissure, grandeur, couleur, odeur, vertus et faculté pour couvrir et armer couilles." 6 Panurge's tale simultaneously reworks two accounts of the loss of innocence: the classical myth of the decline from the Golden to the Iron Age and the Biblical myth of the Fall and the expulsion from the Garden. The original, harmonious relationship of God, man and plants is dissolved. Man suffers alienation from both the Creator and His creation and so losses his natural superiority. The negatively signed myth is balanced by a positive message of redemption. A mediating act reestablishes the original harmony, reintegrates man and Nature, restores man to his natural dominance in partnership with the Creator.

Once again, however, Rabelais transforms the redemption myth as he reworks it. Redemption occurs not through divine grace but through the human ingenuity that discovered such a clever use for fig leaves. Man, who had played a passive role in the medlar myth, innocently eating the fruit that would transmogrify him, here actively participates in his salvation. For all that, he does not become more godly but, having adopted vegetal methods and devices to protect his person, seems more plant-like both in appearance and behavior. The mediator that effects the redemptive act is not Christ, the spirit made flesh, but flesh itself, the phallus, metonymically figured by the codpiece.

Rabelais's version of the Fall replaces a redemptive process dependent on divine intervention with an evolution governed entirely by organic matter and human need. His transformation of Biblical texts may seem shocking, as well it was meant to be. Parody exists to surprise and provoke laughter, and eventually to stimulate reflection by its incongruities and comic reversals. Yet, however surprising the conjunction of plants, man and God may be to twentieth-century readers, it was less foreign to a reader of the 
sixteenth-century, in whose thought and culture it found familiar resonances. Plant and human anatomy were frequently associated in the popular culture of the day, particularly during carnival when barriers of every kind were dissolved. The general atmosphere of moral licentiousness made it possible to give sexual significance to even the most innocent objects and to see erotic configurations in vegetal forms. Large fruits and vegetables of phallic proportions were borne through the streets in rowdy processions. According to Claude Gaignebet, hemp (of which Pantagruelion is commonly acknowledged to be a species) was in particular the object of fervent cult activity: fertility rites, festive dances to assure that the maturing plants would grow straight, tall, smooth and light in color all drew attention to the properties and physical features hemp shared with the phallus. ${ }^{7}$ Popular traditions influenced the literary imagery of the period, inspiring comic poets like Francesco Berni and his friends, contemporaries of Rabelais with whom he may well have been familiar. ${ }^{8}$ Their capitoli praised a variety of unworthy objects, especially fruits and vegetables bearing the round and/or elongated shapes that allowed them to serve as metaphorical figures of the phallus in elaborate dirty jokes the poets circulated among themselves. ${ }^{9}$

Popular conceptions of humankind's relation to the vegetal realm are themselves part of a larger world view that tended to draw analogies between natural phenomena rather than make distinctions. Terraculturalists conceived of the world as a garden where all things bore the imprint of the celestial Gardener and conformed to His divine plan. ${ }^{10}$ Plants and humans, sown by the same hand, were related parts of creation. Once more the affiliation of the human and vegetal realms was most evident in their reproductive systems, which often bore physical resemblance to one another. The mandrake, with its forked root, had long been likened to the human form, while the suggestive shapes of orchids, mushrooms and citrus fruit led early botanists to compare them with human genitalia. The analogy gained strength from the fact that the different branches of science, barely distinguishable themselves in sixteenth-century Europe, had not yet developed their own highly specialized vocabularies. As a result, doctors and terraculturalists frequently gave to plant features the names of human limbs and organs, and vice versa. Rabelais himself linguistically assimilates human and vegetal reproductive systems in the braguette myth, calling the plants' protective devices codpieces ("braguettes naturelles") and referring to human semen as seed ("germe"). Natural phenomena that shared the same origins, terminology and physical appearance also displayed the same virtues. In sixteenth-century Europe, plants were particularly sought out and esteemed for their curative powers 
- powers located in the phallus as well. Rabelais recalls the phallus' healing virtues in Rondibilis's advice to Panurge, whose need for sexual satisfaction is termed a physical ailment ("aiguillons de la chair" [529]). The doctor heartily recommends the "acte Venerien" in which the exercise of the phallus will relieve all his discomfort. All parts of creation received from the Creator their particular virtue, which were in turn reflections of His own divine virtues. The curative powers of plants and the phallus originate in Christ and reflect His ability to cure both physical and spiritual wounds and ultimately the wound introduced by original sin, to restore to God the Father a world once more made well and whole.

Thus we see that while, on the one hand, the association of plant with humans and then humans with Christ served Rabelais's comic purposes, it was also part of a world view that drew together apparently different realities to discover their common ground. The analogies that sixteenthcentury terraculturalists saw between plant and human anatomy helped them better to understand both the peculiar virtues and qualities of each system, as well as those they shared. The phallic and the divine engaged in a similar dialogue of reciprocal illumination. The narrow, limited categories into which Medieval thought classified reality are replaced by a wider, more tolerant vision focusing on the bonds that linked together all creation rather than on the differences that isolated and alienated its various components. In Rabelais's last redemption myth, the praise of Pantagruelion, the comic substitutions found in the medlar and braguette myths take place once more. In "Pantagruelion," however, the transitions from one level of reality to the next are fully articulated, showing how the vegetal, the human and the divine are related, how propagation, technical progress, and salvation history are linked in the same continuum.

The resemblance that the Pantagruelion chapters' organization bears to the popular herbals of the day clearly establishes the plant's vegetal identity form the very beginning. The first chapter gives a physical description of Pantagruelion so graphic as to recall and even to assume the role of the visual image with which herbals initially introduced a plant to their readers. Yet, just as the herbals' woodcuts were more often symbolic than truly accurate illustrations, ${ }^{11}$ so the description of Pantagruelion suggests a reality other than the vegetal one it figures. Pantagrualion's formal features clearly identify it with the phallus. Adjectives stressing height, length, roundness, hardness or pointedness recur frequently in the description of the plant or its parts. The root is: "durette, rondelette, finante en poincte obtuse, blanche, à peu de fillamens, et ne profonde en terre plus d'une coubtée." The trunk is: "unicque, rond, ferulacé, verd au dehors, blanchiss- 
ant au dedans, concave... ligneux, droict, friable, crenelé quelque peu à forme de columnes legierement striées, plein de fibres." The leaves are: "longues trois foys plus que larges, verdes tous jours, asprettes comme l'orcanette, durettes, incisées autour comme une faulcille, et comme la betoine, finissantes en poinctes de sarisse macedonicque, et comme une lancette dont usent les chirurgiens." The seed is: "numereuse autant que d'herbe qui soit, sphaericque, oblongue, rhomboïde, noire claire et comme tannée, durette, couverte de robbe fragile, delicieuse à tous oyseaulx canores." Pantagruelion's considerable size is lauded, but most particularly when it is planted in a medium that is "doux, uligineux, legier, humide sans froydure." As though to retrace the vital surge of power at the origin of all of Pantagruelion's achievements, the text itself follows an ascending, progressive order, setting forth the plant from its roots to its peak, culminating with "la semence [qui] provient vers le chef du tige, et peu au dessoubs" (602-04).

Despite its decidedly phallic configuration, Pantagruelion remains a bisexual plant. Rabelais, imitating the ancients, identifies both a male and a female strain of Pantagruelion and distinguishes between them according to their respective vigor and strength. Alongside the virile plant just portrayed, Rabelais describes a female species, differing from the male by its white flowers, dearth of seed, wide leaves and diminutive size. Like the medlar, which prefigured its role in an earlier redemption myth, Pantagruelion emblematizes human sexuality in a figure of curiously androgynous and/or hermaphroditic quality, at the same time sexually uncertain and sexually all-inclusive.

Once.Pantagruelion's formal properties have associated it with the source of regenerative energy, Chapter 50 presents the means of releasing the vital force. Pantagruelion is composed of an external, woody part ("partie ligneuse"), which must be stripped away ("excortiquer"), pounded ("contundre") or broken ("briser") to obtain the inner fibers, in which resides all the plant's value. The inner fibers will be variously treated and worked, transformed and put to a multitude of uses in following chapters. The outer fibers, Rabelais twice reminds us, are "inutile" except "à faire flambe lumineuse, allumer le feu et, pour l'esbat des petitz enfans, enfler les vessies de porc" or "pour sugser et avecques l'haleine attirer le vin nouveau par le bondon"(605). The woody part, which had once served as a container enclosing the plant's precious fibers, here serves as a vessel allowing the passage of formless, spiritual substances: the air that ignites the fire, the breath that inflates the bladders and inhales wine, the wine that inebriates. In each case, the passage effects a transformation, producing 
a more elevated state: igniting, inflating, inebriating. Pantagruelion shares with the phallus the same duality of inner and outer, useful and useless, spiritual and material. Yet once more its sexual identity slides between female and male. On the one hand, it is the protective enclosure that assures the precious inner fibers will reach maturity. On the other, it is a vessel, transporting spiritual matter of transformational powers, filling much the same function as that ascribed to the phallus in Gargantua's letter to his son: restorer of the race, vessel bearing the seed that will both reproduce the father's image and give it new form in his progeny, mediator between the present and a future that becomes so glorious with each successive generation that the gods have good cause to fear for the continued security of their reign.

Once the plant's physical properties have been established, the Pantagruelion chapters again follow the example of the herbals and penetrate beneath the plant's surface to reveal its hidden virtues. Pantagruelion's relation to the phallus undergoes a similar change. Their resemblance no longer depends on a likeness in formal features, but on the shared procreative energy they both contain. That energy is first exerted in the material realm. Pantagruelion's role in various domestic chores, trades and professions, its ability to provide employment, goods and services are set forth in an ever-proliferating list of accomplishments, proving that, in the domain of human endeavor, Pantagruelion is as fertile and productive as the phallus in the propagation of the race. The enumeration of Pantagruelion's achievements culminates in the most prodigious of the plant's feats: when used in sails it joins the far corners of the earth, truly a copula mundi. Here too the plant is associated with a vessel, now a sea-faring one giving human beings passage between geographically distant points. While Pliny, with whom the topos originates, ${ }^{12}$ condemns humankind's audacity in challenging the unknown, Rabelais celebrates the wonders realized by navigation in his time. Through Pantagruelion, humans extend their horizons not only spatially but gnostically as well, gaining knowledge of foreign lands that Nature had denied to the rest of her creation. Pantagruelion advances humans literally and figuratively over birds, "quelque legiereté de pennaige qu'ilz ayent et quelque liberté de nager en l'aęr que leur soit baillée par Nature" (613), restoring him to their natural dominion. As a phallic figure, Pan tagruelion embodies the procreative powers that human beings share with all Nature's creatures and that fully integrate them into her domain. Now Pantagruelion becomes as well an emblem of ingenuity and technical progress, peculiarly human virtues assuring humankind's uniqueness and its supremacy over the natural order. 
Human supremacy in the natural realm easily leads to visions of their conquest of the supernatural as well. The Olympian gods, fearing human technology will continue its rapid advancement unimpeded, forsee the day when the giants will invade the very heavens. As though to recall the origin of the plant's amazing power, it is explicitly associated with the phallus at the very momment it threatens to unseat the gods. While the gods may be unnerved by Pantagruelion and its accomplishments, they are terrified by the prospect of what even more wondrous plant the giant's children might invent to use against them. The true source of the gods' fear is not Pantagruelion but the reproductive power of the giant's braguette and the fertile ingenuity of its issue.

To be sure, Rabelais's brief history of human progress concludes in gross exaggeration and comic reversal. Pantagruclion poses no threat to divine authority: the divinities are the mythological figures of classical literature; their fear is wildly disproportionate to the object inspiring it; they are made to appear all the more insubstantial and ridiculous by the pun that transforms their heavenly abodes into common inns and taverns. Yet, twice more, in a less facetious fashion, the narrator refers to Pantagruelion's role in helping humankind achieve quasi-divine status by describing the plant's use in funerals, the rites marking the passage from mortal to immortal life. Pantagruelion, placed as a garland on the head of the deceased, serves, like the sacred laurel, myrtle or ivy, as a mediator helping the soul of the dead to negotiate the passage between earthly and supernatural existence. In a similar fashion, Pantagruelion once more assumes the dual role of protective casing that prevents the ashes of the deceased from mingling with those of the funeral pyre, and of transporting vessel that allows them to pass from one state to another while preserving them to be resurrected to eternal life on the day of the Last Judgment. Here the power embodied in the phallus and transferred to human ingenuity becomes the source of redemption and the means of gaining everlasting life.

The Pantagruelion episode links procreation to human learning and technical knowledge, and shows how they participate in the continuous unfolding of divine revelation. Although the chapters trace a steady progress towards the day when humans will be restored to their rightful position alongside God the Father, the unity and wholeness they promise is never fully realized, remaining states of perfection beyond human experinece. Humankind can only await with confidence and trust the moment that God, in His infinite wisdom and goodnesss, should choose to bring them into being. Until then, Rabelais, in keeping the the synergetic theology of his Evangelism, sees humans exerting themselves to the fullest extent of his 
human capacities to collaborate with God in the evolution of salvation history. While man's contribution is necessarily determined by the material nature of his terrestrial being, that qualification need not be construed as a limitation. The redemptive act the Pantagruelion chapters depict originates on the lowest level of animant existence, the vegetal, reversing the platonic myth of a universe ruled by divine love emanating from the most elevated spheres. Man's technical and spiritual advancement are not determined by heavenly influences, but take as their model the organic patterns of generation and growth that assure the propagation of the human race. Rather than a Messiah come to deliver humankind from an imperfect state, the redeemer is a phallic figure, more adequate to post-lapsarian existence, overcoming imperfection through a continuous process of transformation, proliferation and dispersion.

The Pantagruelion chapters discover the same phallic powers at work on every level of human existence: matter, bearing a vital, protean substance, helps humankind advance towards a state of wholeness and perfection through a seemingly endless series of regenerative acts. The text, which bears the vision of phallic potency, itself displays that same energy, performing its own creative act, into which it actively draws its readers.13 Rabelais explicitly links Pantagruelion and the printed word when, imagining a world without the wonderful plant, his narrator asks: "Sans elle, que feroient les tabellions, les copistes, les secretaires et escrivains? Ne periroient les pantarques et papiers rantiers? Ne periroit le noble art d'imprimerie?" (612). Although the loss of paper is the object of the narrator's lament, it is the printed words covering paper's surface that give paper meaning and that furnish needed employment to the copyists, secretaries, writers and printers. The power embodied by the plant is metonymically transferred from its end product, paper, to the words paper bears.

Paper shares the same relationship with words as Pantagruelion and the phallus do with the vital energy they bear. Words, in turn, share the same relationship with meaning, as illustrated by the images frequently used by Rabelais to figure his own text. The well-known apothegm of the marrow bone distinguishes between uscless, inanimate matter and the life-giving essence it bears. Readers are invited to break the worthless shell just as Pantagruelion's users must "contundre" or "briser" "la partie ligneuse" (by its qualifier alone suggesting lines of text) to appropriate its power. The phallus, Pantagruelion and the text all act as vessels bearing vital, regenerative energy.

The Rabelaisian text, which figuratively conforms to the purpose literally served by the phallus, generates itself according to the principles of 
transformation and renewal that govern the phallus' own procreative act. We have already seen how Rabelais rewrites Biblical and classical texts, transforming the redemption myth by locating its origins in human need and desire rather than divine will: appropriating Pliny's description of hemp/flax, but replacing his reproval of man's audacity with unabashed admiration. Vergil's negative prophecy, "Nec Deus hunc mensa, Dea nec dignita cubili est" (Eclogues IV.63), undergoes a similar transformation in the gods' affirmation that one day Pantagruel's offspring will be able to "s'asseoir à table avecques nous, et nos déesses prendre à femmes" (614). Here, however, as often happens, Rabelais rewrites himself as well as Vergil. Vergil's verses originally appeared in Panurge's consultation of the "sors Virgilianes" at the beginning of the Tiers Livre's search for an unequivocal answer (447). While at that time the verse had denied Panurge the happy, fruitful future to which he aspired, it now promises unlimited felicity and power to humankind. The utopian overtones of "Pantagruelion" bring to mind the ideal world that had occupied the same position in the closing chapters of the preceding book, the Abbey of Thélème. Rabelais himself twice recalls it by name in the Tiers Livre's closure, ${ }^{14}$ as though to link his new conception of a redeemed humanity to his earlier one and to absorb it in a more perfect vision. Rewriting, inspired by a need to overcome the inadequacy of the past, becomes a reproductive act, itself a redemptive movement towards a fullness of meaning. The text, like the phallus, bears the image of the past but renews and regenerates the past while carrying it into the future.

Literary creation depends on the past and cannot take place ex nihilo. Like human procreation, it also requires co-participation and depends on reader involvement in the generation of meaning. The active role that the reader must play in realizing the text's significance is modelled by the techniques Pantagruelion's users employ to break down the "partie ligneuse" and release the plant's virtues:

Quelques pantagruelistes modernes, evitans le labeur des mains qui seroit à faire tel depart, usent de certains instrumens catharactes, composez à la forme que Juno la fascheuse tenoit les doigtz de ses mains liez pour empescher l'enfantement de Alcmene, mere de Hercules, et à travers icelluy contundent et brisent la partie ligneuse, et la rendent inutile, pour en saulver les fibres (605).

The pantagruelistes' instruments are compared in form to the way Juno held her hands in a useless attempt to prevent Alcmena from giving birth to Hercules. But, while Juno's act was meant to be destructive, the 
pantagruelistes resort to violence only as a means of rescuing, of "saving" the plant's most valuable parts. In yet another sexual inversion, rebirth and regeneration are here associated with images of motherhood. Readers, like the pantagruelistes, will be invited to become involved in the maieutic process which brings forth latent ideas. The text actively engages readers in the procreative act it is performing. From the first chapter of the episode, the narrator begins to draw his readers into the text through the use of paraphrases, withholding the names of objects, designating them instead by circumlocutions, and asking the reader to supply missing information from clues given in the text. At first paraphrases are limited to designations of seasons ("les feries des pescheurs," "à la nouvelle venue des hyrondelles," "lorsque les cigalles commencent à s'enrouer" [604]). They increase in number and complexity, however, as the episode progresses, gradually requiring greater effort of the readers. Chapter 51 presents a prolonged litany of trades and professions to which Pantagruelion is essential, each time describing the plant's specific use through a paraphrase in the form of a question ("Sans elle, comment seroient portez les playdoiers des advocatz à l'auditoire? Comment seroit sans elle portée le plastre à l'hastellier? Sans elle, comment seroit tirée l'eaue du puyz?.." [612]). Here the paraphrase joins the urgency of the interrogative form with the riddle's promise of hidden truth for the individual who resolves it, involving the reader in the pursuit of meaning.

The paraphrase and its importunities give way to the more active exchange of the dialogue in the final chapter of the episode. There the narrator directly addresses his readers, harrying them with personal questions, weighing their response, anticipating and dismissing their faulty reasoning, bullying and shaming them if they are too slow to respond. Readers are drawn into the text by the dialogue, even appearing on the printed page in the "vous" that repeatedly designates them, and made to play an active role in text production.

The narrator, however, is not content with mere verbal participation and demands physical involvement of his readers as well. He engages them in an experiment to test Pantagruelion's incombustibility, instructing them to wrap an egg in Pantagruelion and place it in the fire. Upon removing it, readers will find that the egg has been hard-cooked but that Pantagruelion remains unaltered by its ordeal. As in a recipe, text and reader combine efforts in a progressive sequence, supposedly working together to establish the true nature of Pantagruelion. 
The narrator's instruction to his readers are, of course, ironic. Those who attempt the experiment soon find themselves performing the same gratuitous gyrations as Diogenes around his barrel. Rabelais has taken all possible measures to assure that no single meaning be given to his plant. He has obscured its origins by altering and confusing the literary traditions from which it came. He has concealed its identity by giving it the newly-coined name "Pantagruelion" in honour of a fictional hero. He has multiplied its meanings by locating its virtue not in the plant itself but in the varied and multiple uses to which it is put. $\mathrm{He}$ has even rendered uncertain the gender of this decidedly phallic figure, and adds to the confusion by calling it alternately "le Pantagruelion" and " $l a$ plante" and referring to it by both masculine and feminine pronouns. The text's plurality has given it the same procreative power as those embodied in the plant itself: the Pantagruclion chapters have also been fruitful, yielding almost as many interpretations as readers. ${ }^{15}$ In the concluding verses the narrator himself encourages this proliferation and dispersion:

\footnotetext{
Venez ici recongnoistre nos biens,

Et emportez de nostre herbe la grene.

Puys, si chez vous peut croistre, en bonne estrene

Graces rendez es cieulx un million;

Et affermez de France heureux le regne

On quel provient Pantagruelion (619).
}

Readers are invited to partake of Pantagruelion, to carry it off, to plant it in their native soil. There it will be transformed, demonstrate new virtues and find new uses according to the conditions surrounding it. Transferral, change, dissolution of an original unity - all produce the same positive results as the breaking down of Pantagruelion's wholeness, transforming the lands where the plant is introduced, bringing them growth and prosperity. Those who bear off Pantagruelion's seed are themselves transformed, endowed with a verbal prolixity to match the plant's prolificacy. Their million expressions of gratitude make them disseminators of both the plant and its changing meanings. Infused with the energy embodied by both the plant and the text to which it is consigned, readers themselves become agents of transformation and proliferation, participating in a redemptive movement towards a moment of truth continuously displaced into the future.

Rabelais's redemption myths restore man to quasi-divine status, but they make that process a specifically human activity. Organic matter assumes 
the role played by the divine in a regenerative movement sustained by the successive transformations peculiar to post-lapsarian existence. Ironically, transformation as a process, by its very dynamism and vitality, precludes the realization of the absolute, changeless state of perfection to which it aspires. Reconciliation, the moment of fullness, remains exterior to the process in which humankind, text and reader are actively engaged, guaranteeing the endless productivity and advancement of each.

\section{Marquette University}

1 Dennis Costa, Irenic Apocalypse: Some Uses of Apocalyptic in Dante, Petrarch and Rabelais, Stanford French and Italian Studies 21 (Saratoga, Calif.: Anma Libri, 1981); Edwin Duval, "Pantagruel's Genealogy and the Redemptive Design of Rabelais's Pantagruel," PMLA, 99 (1984), 162-77; David Quint, Origin and Originality in Renaissance Literature: Versions of the Source (New Haven: Yale University Press, 1984).

2 In addition to the studies cited above, see Kitzie McKinney, "Diversions of Transformations in Rabelais's Medlar Myth," French Review, 59 (1986), 546-52.

3 "Mesple," A Dictionarie of the French and English Tongues, comp. Randle Cotgrave, reproduced from the first edition, London 1611 (Columbia, S.C.: University of South California Press, 1950).

4 See Charlotte F. Otten, Environ'ed with Eternity: God, Poems and Plants in Sixteenth and Seventeenth Century England, (Lawrence, Kansas: Coronado Press, 1985), pp.86-7.

5 Kitzie McKinney rightfully argues that in transforming the Christian myth, Rabelais translates it irrevocably to a material register, "sabotag[ing] the idea of a spiritual trajectory leading away from carnal, animate being" (550).

6 François Rabelais, Oeuvres Complètes, ed. Pierre Jourda, 2 vols. (Paris: Garnier, 1962), 1:435. All further references will be to the first volume of this edition and will be given in the text by page number.

7 Claude Gaignebet, Le Carnaval (Paris: Payot, 1979), pp.65-86.

8 See N. N. Condeescu, "Le Paradoxe bernesque dans la littérature française de la Renaissance," Beiträge zur romanischen Philologie 2 (1963), 27-51, and Marcel Tetel, Rabelais et l'Italie (Florence: Olschki, 1969), pp.92. Both scholars believe that Rabelais knew Berni's work and was inspired by it.

9 For a discussion of the erotic metaphors in the poetry of Berni and his friends, see Paolo Cherchi, "L'Encomio paradossale nel manierismo," Forum Italicum, 9 (1975), 368-84, and Silvia Longhi, Lusus: il capitolo burlesco nel Cinquecento (Padova: Antenore, 1983).

10 Interested readers will find a complete description of the terraculturalists' mind frame in Charlotte Otten's informative study.

11 For a discussion of the woodcut's function in early herbals, see Agnes Arber, Herbals: Their Origin and Evolution (Cambridge: Cambridge University Press, 1938), pp.146-7, 193.

12 Pliny attributes the ability "to carry the whole world to and fro" not to hemp but to flax in Book 19 of his Natural History.

13 Terence Cave identifies a similar transferral in the chapter describing young Gargantua's clothing. His braguette, adorned with fruits and flowers to suggest the fruitfulness of the member it covers, is displaced by a text that itself assumes the role of designating 


\section{0 / Renaissance and Reformation}

plenitude. See The Cornucopian Text: Problems of Writing in the French Renaissance (Oxford: Clarendon Press, 1979), pp.185.

14 The Abbey is named once in the opening lines, where the narrator identifies Frère Jean by his full title of "Abbé de Théléme"(602), and again in the closing lines, where Pantagruel announces his intention to make use of the wonderful plant to replace all the doors and windows of the abbey (618).

15 For a collection of various interpretations of the Pantagruelion episode, see V. L. Saulnier, "L'Enigme de Pantagruelion ou du Tiers au Quart Livre," Études Rabelaisiennes 1 (Genève: Droz, 1956), pp.48-72. Other readings of "Pantagruelion" include: Alfred Glauser, Kabelais créateur (Paris: Nizet, 1964), pp.223-8; Floyd Gray, Rabelais et l'écriture (Paris: Nizet, 1974), pp.160-62; François Rigolot, Les Langages de Rabelais, Études Rabelaisiennes 10 (Genève: Droz, 1972), pp.144-52; M.A. Screech, Rabelais (Ithaca, N. Y.: Cornell University Press, 1979), pp.286-9. 